\title{
Larvivorous potentiality of Puntius tetrazona and Hyphessobrycon rosaceus against Culex vishnui subgroup in laboratory and field based bioassay
}

\author{
Mousumi Barik', Indranil Bhattacharjee ${ }^{1,2}$, Anupam Ghosh ${ }^{1,3}$ and Goutam Chandra ${ }^{1 *}$ (D)
}

\begin{abstract}
Objectives: This study assessed the predatory potentiality of two unexplored fishes, Puntius tetrazona and Hyphessobrycon rosaceus on Culex vishnui subgroup larvae in order to utilize natural resources to diminish mosquito population. Larval feeding rate was evaluated in laboratory under varying prey density and volume of water. The experiment was extended to semi field condition.

Results: Puntius tetrazona and H. rosaceus consumed from 66 to 600 and from 87 to 718 Cx. vishnui larvae respectively in laboratory condition at 10 prey density levels (100-1000 larvae) at an increment of 100 larvae at 2 I water volume. In semi field condition, a $78 \%$ reduction in larval density was observed at day 30 post introduction of $P$. tetrazona, whereas $91 \%$ reduction was noted on day 21 for $\mathrm{H}$. rosaceus and in the subsequent samples no mosquito larvae were found in ditches. Withdrawal of predators from the ditches resulted gradual increase in larval density. Laboratory and semi field bioassay of both the species indicated their potentiality as efficient mosquito larval predator though $H$. rosaceus exhibited better performance than P. tetrazona. It is recommended to utilize these natural resources to diminish mosquito population in the countries of their native range.
\end{abstract}

Keywords: Biological control, Puntius tetrazona, Hyphessobrycon rosaceus, Culex vishnui subgroup

\section{Introduction}

Mosquitoes are blood sucking dipteran insects that act as vector of several important life threatening diseases, including malaria, lymphatic filariasis, chikungunya, dengue fever and Japanese encephalitis [1,2]. To overcome these diseases, the reduction in the population size of mosquitoes is essential. The most effective means to control mosquitoes is the application of chemical insecticide. However, long term use of synthetic insecticides is harmful for human health and non target animal and arthropod populations and an important cause of environmental pollution. Also mosquitoes can become

\footnotetext{
*Correspondence: goutamchandra63@yahoo.co.in

${ }^{1}$ Mosquito Microbiology and Nanotechnology Research Units, Parasitology Laboratory, Department of Zoology, The University of Burdwan, Bardhaman, West Bengal, India

Full list of author information is available at the end of the article
}

resistant to the synthetic chemicals after prolonged use. To overcome this problem, mosquito larvae management through biological control is preferred all over the world as an alternative and cost effective method [1-6]. Fishes are an important part of aquatic food chain and the mosquito larvae are significant part of their diet. In some of the previous studies, it was showed that the use of larvivorous fishes could represent a valid method for the biological control of mosquito immature stages in controlled and small natural habitats $[7,8]$.

The predation potentiality of a predator generally increases with the increase in prey density [9]. Except prey density, some other factors like species of prey item and its size, the species and size of predator, presence of vegetations in the aquatic habitat, water parameters and its quality, illumination intensity and prey capture or 
feeding method of the predator also influence the feeding efficacy of aquatic predators [1, 2, 5, 6, 10-15].

Culex vishnui subgroup is an important vector of Japanese encephalitis (JE) in India. JE is the most important viral encephalitis in Asia, especially in rural and suburban areas where rice culture and pig farming coexist [16]. A current estimate suggests that there are about 50,000 cases of JE globally having 15,000 death/year; in India [17]. This species breed in water with luxuriant vegetation mainly in paddy fields, shallow ditches and seasonal pools.

Puntius tetrazona (Bleeker, 1855), the tiger barb or Sumatra barb, belonging to the order cypriniformes and the family Cyprinidae is a tropical fish. The natural geographic range of this species extends throughout the Malay Peninsula, Sumatra and Borneo, with unsubstantiated sightings reported in Cambodia [18, 19]. Tiger barbs are also found in many other parts of Asia [20]. Tiger barbs prefer clear or turbid shallow waters of moderately flowing streams. They are brownish yellow in colour and characterized by presence of four vertical black stripes in body and have red fins and snout. Hyphessobrycon rosaceus Durbin, 1909, the rosy tetra belongs to the order Characiformes, family Characidae. It is a small species of fresh water fish from the South American countries of Guyana and Brazil $[21,22]$. In the wild they come from areas with soft acid water, but the adults can tolerate natural or even slightly alkaline water. It is silver white in colour and characterized by red fins.

The present study was carried out to assess the predatory potential of Puntius tetrazona and Hyphessobrycon rosaceus on Culex vishnui subgroup larvae under laboratory conditions with reference to prey density and search area. The biocontrol efficacy of the two species was also assessed under semi field conditions.

\section{Main text}

\section{Materials and methods}

\section{Collection of mosquito larvaes}

Larvae of Culex vishnui subgroup (Diptera: Culicidae) were collected by fine netting from rice fields and different other aquatic bodies of Burdwan $\left(23^{\circ} 16^{\prime} \mathrm{N}, 87^{\circ} 54^{\prime} \mathrm{E}\right)$. They were settled and reared for several generations in the laboratory. Third instar larvae were used for the experiments. The larvae grown in laboratory were fed with powdered dog biscuits [23].

\section{Collection, maintenance and breeding of fishes and alternative prey organisms}

The experiments were done in the Mosquito Research Unit, Parasitology Laboratory, Department of Zoology, The University of Burdwan, West Bengal, India. One pair of mature female and another pair of mature male of P. tetrazona (about $7.3 \mathrm{~cm}$ long) and $H$. rosaceous (about $3.9 \mathrm{~cm}$ long) were collected from the market. Males and females of each species were placed separately in four fiber glass water tanks $(45.72 \mathrm{~cm} \times 25.4 \mathrm{~cm} \times 25.4 \mathrm{~cm})$ containing $30 \mathrm{l}$ of tap water $(\mathrm{pH} 7.2)$ and clusters of fine leaved plants with $1 \mathrm{~kg}$ of sand and $0.5 \mathrm{~kg}$ of pebbles at the bottom and maintained in the laboratory. The tanks were kept in dim light at room temperature on an average of $27.5^{\circ} \mathrm{C}$. Fishes were provided with required amount of fish food and Tubifex sludge worms. When the females were full of eggs and fatty enough and the males were brightly colourful, they were released in a spawning tank of same size and conditions containing slightly acidic water $(\mathrm{pH}$ 6.5). Spawning took place within 2 days and as soon as the eggs were found the fishes were withdrawn. After breeding the next generation stock population was used during bioassay experiment. Chironomid larvae (Order Diptera, Suborder Nematocera) and damselfly nymphs (Order Odonata, Suborder Zygoptera,) were collected from the wetlands located within the Burdwan University campus and settled in laboratory trays.

\section{Evaluation of predation potential on Cx. vishnui larvae}

The predatory potential of the fishes was assessed under varying volumes of water $(2,4$ and $8 \mathrm{l})$ and varying densities of prey, i.e. third-instar larvae of $C x$. vishnui. A single fish was released to predate on a specific prey density of 100-1000 with an increment of 100 larvae in each step (i.e., 10 density levels), in each water volume. For each water volume and prey density combination, three replications were done to assess the feeding trend of different individuals of the same fish species of the same size group. Control experiment was also set for different prey density and for different water volumes. The ranges of size and weight of $P$. tetrazona used in the experiment were $5-5.4 \mathrm{~cm}$ and $1.2-1.35 \mathrm{~g}$. For $H$. rosaceous the ranges of size and weight used in the experiment were $3.4-3.6 \mathrm{~cm}$ and $0.91-0.96 \mathrm{~g}$ respectively. The experiments were carried out on seven different days, under similar conditions. After 7 days, data of altogether 630 observations were noted ( 3 levels of volume $\times 10$ levels of prey density $\times 7$ days $\times 3$ replicates) per fish species. After each day the number of prey consumed was counted and the prey density was maintained constant by addition of equivalent numbers of prey. Multiple regression equation analysis was carried out considering predation by Puntius tetrazona and Hyphessobrycon rosaceus fish species $(\mathrm{Y})$ as dependent variable on variable conditions of mosquito larvae density $\left(\mathrm{X}_{1}\right)$ and water volume $\left(\mathrm{X}_{2}\right)$. The data related to predation rate were subjected to four-way factorial ANOVA $(\mathrm{p}<0.01)[24]$. 


\section{Selection of mosquito larvae in presence of alternative prey} In a laboratory bioassay, a single individual of each predatory fish was allowed to predate on 200 specimens of each of three different preys, i.e. chironomid larvae, damselfly nymphs and $C x$. vishnui subgroup kept in a single glass aquarium containing $2 \mathrm{l}$ of water. After $24 \mathrm{~h}$, the rate of consumption of each kind of prey was calculated for each fish. The experiments were repeated thrice for each predator fish species.

\section{Evaluation of predatory efficiency in semi field condition}

Predatory potentiality of the fishes was carried out in ditches located adjacent to rice fields of a village, Jotsadi, Burdwan, West Bengal, India. Average size of the ditches was $4 \mathrm{~m}$ long, $2 \mathrm{~m}$ wide and $0.3 \mathrm{~m}$ deep and drained excess rain water from rice fields. Twelve such ditches were selected which were disconnected from one another and sampled randomly for mosquito larvae to assess density [25] prior to introduction of the fishes. In the collected samples, the majority of the mosquito immature stages (larvae and pupae) were identified as $C x$. vishnui subgroup. Few individuals were Anopheles subpictus sensu lato. In each of 5 ditches, 30 individuals of $P$. tetrazona were introduced. In each of other 5 ditches the same number of $H$. rosaceous were introduced. Two ditches were considered as control (without introduction of any fish). After introduction of the fishes, the average density of mosquito larvae in these ditches was estimated at 3-day interval for 30 days. After 30 days, fishes were removed from the ditches with fishing net and density of larvae was assessed every 3 days interval up to next 30 days. After laboratory and semi-field feeding experiments, all the fishes under study were released in a nearby pond in living condition in the University campus protected area. Data were subjected to t test analysis and distribution plot was drawn using XLSTAT software [24].

\section{Results}

\section{Predatory potential}

The fishes consumed considerable numbers of thirdinstar $C x$. vishnui subgroup though variation in feeding rate was noted depending upon prey density and the volume of water. The prey consumption ranged from 66 to 600 for $P$. tetrazona and from 87 to 718 for $H$. rosaceus in laboratory condition against third-instar mosquito larvae/day at 21 water volume. With the increase in water volume (search area), the predation rate dwindled but the prey consumption increased linearly with the prey density irrespective of water volume (Additional file 1: Fig. S1a, b). The result from multiple regressions for predation of mosquito larvae by $P$. tetrazona was:
$\mathrm{Y}=70.794 \mathrm{X} 1-3.814 \mathrm{X} 2+11.994$ and for $H$. rosaeus the corresponding equation was $\mathrm{Y}=81.468 \mathrm{X} 1-0.488$ $\mathrm{X} 2+16.748$. The results in both the cases suggested that the rate of predation $(\mathrm{Y})$ by both predator species was positively correlated with prey density $\left(\mathrm{X}_{1}\right)$ and inversely related to water volume $\left(\mathrm{X}_{1}\right)$. The independent variables $\left(X_{1}\right.$ and $\left.X_{2}\right)$ were strong predictors of feeding rate because for each fish species the multiple correlation coefficients $\left(R^{2}\right)$ were nearer to $1(0.949$ and 0.967 for $P$. tetrazona and $H$. roseus respectively).

The results of the four-way factorial ANOVA (Table 1) revealed significant differences in prey consumption among them. The daily predation rate at a specific prey density did not differ significantly for the 7-day experimental period for a particular predator species.

\section{Selection of mosquito larvae in presence of alternative prey}

Results presented in Table 2 clearly show that mosquito larvae were the prey of choice among the three prey items viz. mosquito larvae, dragon fly nymphs and chironomid larvae.

\section{Field evaluation of predatory efficiency}

The result presented in Additional file 1: Fig. S2 indicates that the fish predators reduced the abundance of the mosquito larvae in all experimental ditches respect to the control ditches. Before introduction of the fishes, the mean density of mosquito larvae available in the ditches (control experiment) ranged between 252 and 275 (no. of larvae/dip). After the fishes were introduced, 91\% reduction of mosquito larvae was observed on day 21 for $H$. rosaceus and $78 \%$ reduction in the density was observed for P. tetrazona on day 30. Withdrawal of the fishes from the ditches facilitated gradual increase in larval population in the next 30 days. The mean densities of mosquito larvae was significantly reduced in presence of the fishes in comparison to the control ditches without fishes (for $P$. tetrazona: $\mathrm{t}=10.933$, for $H$. rosaceus: $\mathrm{t}=12.673$; $\mathrm{df}=53$, $\mathrm{p}<0.0001$ ), as shown in Additional file 1: Fig. S3.

\section{Discussion}

This is the first report on predation of two fish species, $P$. tetrazona and $H$. rosaceus, on mosquito larvae. The present study shows negative correlation between quantity of water and feeding efficiency. This is consistent with data reported in some previous studies on other fish species $[1,2,5,6]$. The foraging behavior of the fishes altered with the increase in search area; as a result consumption of the mosquito larvae decreased $[1,2,5,6]$. After 30 days of introduction of fishes in the treated ditches larval density greatly reduced as also reported by other authors [1, 
Table 1 Results from four-way factorial ANOVA of insect immature stages (Culex vishnui subgroup larvae) predation by Puntius tetrazona and Hyphessobrycon rosaceus larvivorous fishes at $\mathbf{1 0}$ different densities of insect immature stages and 3 different volumes of water, for 7 consecutive days

\begin{tabular}{|c|c|c|c|c|c|}
\hline Source of variation & Sum of squares & df & Mean square & $\mathrm{F}$ & $p$-value \\
\hline Fish species (FS) & $1,548,544.11$ & 1 & $1,548,544.11$ & $25,221.24$ & 0.01 \\
\hline Volume of water (V) & $11,755.94$ & 2 & 5877.96 & 95.74 & 0.01 \\
\hline Days (D) & $280,636.60$ & 6 & $46,772.76$ & 761.79 & 0.01 \\
\hline Prey density (PD) & $62,058,653.3$ & 9 & $6,895,405.92$ & $112,305.9$ & 0.01 \\
\hline$F S \times V$ & $11,272.94$ & 2 & 5636.47 & 91.80 & 0.01 \\
\hline$F S \times D$ & $29,339.23$ & 6 & 4389.87 & 71.49 & 0.01 \\
\hline$F S \times P D$ & $390,088.93$ & 9 & $43,343.21$ & 705.93 & 0.01 \\
\hline$V \times P D$ & $43,452.57$ & 18 & 2414.03 & 39.31 & 0.01 \\
\hline$D \times P D$ & $47,654.710$ & 54 & 882.495 & 14.373 & 0.01 \\
\hline$F S \times V \times D$ & 2119.108 & 12 & 176.592 & 2.876 & 0.01 \\
\hline$F S \times V \times P D$ & $54,595.719$ & 18 & 3033.096 & 49.400 & 0.01 \\
\hline $\mathrm{FS} \times \mathrm{D} \times \mathrm{PD}$ & $42,235.833$ & 54 & 782.145 & 12.739 & 0.01 \\
\hline$V \times D \times P D$ & $45,216.105$ & 108 & 418.668 & 6.819 & 0.01 \\
\hline$F S \times V \times D \times P D$ & $30,559.114$ & 108 & 282.955 & 4.609 & 0.01 \\
\hline Residual & $51,574.67$ & 840 & 61.39 & & \\
\hline Total & $64,647,699.00$ & 1259 & & & \\
\hline
\end{tabular}

Table 2 Number (mean \pm S.E.) of Culex vishnui subgroup (Cx. vishnui) larvae, chironomid larvae and damselfly nymphs predated in a period of $24 \mathrm{~h}$ by Puntius tetrazona and Hyphessobrycon rosaceus fishes

\begin{tabular}{lcc}
\hline Insect immature stages & Puntius tetrazona & $\begin{array}{l}\text { Hyphessobrycon } \\
\text { rosaceus }\end{array}$ \\
\hline CX. vishnui larvae & $163.9 \pm 7.8$ & $174.3 \pm 11.10$ \\
Chironomid larvae & $55 \pm 1.3$ & $43 \pm 2.9$ \\
Damselfly nymphs & $48 \pm 1.9$ & $61 \pm 2.4$ \\
\hline
\end{tabular}

$5,6,26]$. Gradual increase in larval density on withdrawal of predator fishes from the ditches in next 30 days further confirms this result. Therefore, these fishes could be used as useful tools for biological control of mosquitoes in different kinds of fresh water habitats like ponds, pools, rice fields etc. Considering the biocontrol potential of $P$. tetrazona and $H$. rosaceus observed in this study, these two fish species could be used as a mean for the control of mosquitoes, especially $C x$. vishnui subgroup. Nevertheless, further studies are needed on the effects on aquatic communities of the use of these fishes in the field, in order to fully evaluate their overall impact on biodiversity and benefits in the control of mosquito populations.

\section{Limitations}

The experiment was not conducted in field condition.

\section{Additional file}

Additional file 1: Figure S1a. Number of third-instar Culex vishnui subgroup (CX. vishnui) larvae per liter of water consumed by Puntius tetrazona under laboratory conditions. For each density of mosquito larvae, the values represented by the bars are means ( \pm SE) of three repetitions in a 7-day observation period. Figure S1b. Number of third-instar Culex vishnui subgroup (CX. vishnui) larvae per liter of water consumed by Hyphessobrycon rosaceus under laboratory conditions. For each density of mosquito larvae, the values represented by the bars are means ( \pm SE) of three repetitions in a 7-day observation period. Figure $\mathbf{S 2}$. Mean density of mosquito immature stages/day observed in a period of 60 days in ditches containing Puntius tetrazona or Hyphessobrycon rosaceus fishes (first 30 days with the fishes and next 30 days after withdrawal of fishes) respect to control ditches without fishes. Figure S3. Distribution plots of t-test (two tailed paired samples).

Abbreviations

ANOVA: analysis of variance; JE: Japanese encephalitis.

\section{Authors' contributions}

$\mathrm{MB}$ collected the fishes, carried out the major part of the experiment and wrote the first draft of the manuscript. IB and AG have conducted parts of the experiments and computed statistical analyses. GC designed the experiment, supervised the work, and helped in critical revision of the manuscript. All authors read and approved the final manuscript.

\section{Author details}

${ }^{1}$ Mosquito Microbiology and Nanotechnology Research Units, Parasitology Laboratory, Department of Zoology, The University of Burdwan, Bardhaman, West Bengal, India. ${ }^{2}$ Department of Zoology, Dr. Bhupendra Nath Dutta Smriti Mahavidyalaya, Hatgobindapur, West Bengal, India. ${ }^{3}$ Department of Zoology, Bankura Christian College, Bankura, West Bengal, India. 


\section{Acknowledgements}

The infrastructure provided by the department of Zoology, The University of Burdwan is thankfully acknowledged.

\section{Competing interests}

The authors declare that they have no competing interests.

\section{Availability of data and materials}

All data generated or analyzed during this study are included in this published article. However, raw data are available from the corresponding author on reasonable request.

\section{Consent for publication}

Not applicable.

\section{Ethics approval and consent to participate}

Approval for animal experiments with two culturable species of fishes was taken from DMC, The University of Burdwan prior to the experiments. The copy of the permission letter is submitted as additional file.

\section{Funding}

No funding.

\section{Publisher's Note}

Springer Nature remains neutral with regard to jurisdictional claims in published maps and institutional affiliations.

Received: 9 July 2018 Accepted: 1 November 2018

Published online: 08 November 2018

\section{References}

1. Ghosh A, Mondal S, Bhattacharjee I, Chandra G. Biological control of vector mosquitoes by some common exotic fish predators. Turk J Biol. 2005;29:167-71

2. Ghosh A, Bhattacharjee I, Ganguly M, Mondal S, Chandra G. Efficacy of some common aquarium fishes as biocontrol agent of preadult mosquitoes. Buletin Penelitian Kesehatan. 2004;32:144-9.

3. Kumar R, Hwang JS. Larvicidal efficiency of aquatic predators. A perspective for mosquito biocontrol. Zool Stud. 2006;45:447-66.

4. Manilal A, Thajuddin N, Selvin J, Idhayadhulla A, Kumar RS, Sujith S. In vitro mosquito larvicidal activity of marine algae against the human vectors, Culex quinquefasciatus (Say) and Aedes aegypti (Linnaeus) (Diptera: Culicidae). Int J Zool Res. 2011;7(3):272-8.

5. Bhattacharjee I, Aditya G, Chandra G. Laboratory and field assessment of the potential fishes as predators of culicine mosquitoes. Biol Control. 2009:49:126-33.

6. Chandra G, Mandal B, Bhattacharjee I, Kundu JK. Biocontrol efficiency of two indigenous fishes Pethia conchonius and Trichogaster chuna against larvae of the mosquito, Culex quinquefasciatus Say, 1823. AARJMD. 2015;2(5):38-52.

7. Chandra G, Bhattacharjee I, Chatterjee SN, Ghosh A. Mosquito control by larvivorous fish. Indian J Med Res. 2008;127:13-27.
8. Chandra G, Ghosh A, Bhattacharjee I, Ghosh SK. Use of larvivorous fish in biological and environmental control of disease vectors. Cameron MM, Lorenz LM, eds. 2013. p. 25-41.

9. Whittingham MJ, Markland HM. The influence of substrate on the functional response of an avian grainvore and its implications for farmland bird conservation. Oecology. 2002;130:637-44.

10. Sutherland WJ, Koene P. Field estimates of the strength of interference between oyster catchers Haematopus ostralegus. Oecology. 1982:55:108-9.

11. Dolman PM. The intensity of interference varies with resource densityevidence from a field study of snow buntings Plectrophenax nivalis. Oecologia. 1995;102:511-4

12. Cresswell W. Interference competition at low competitor densities in blackbirds Turdus merula. J Anim Ecol. 1997:66:461-71.

13. Norris $K$, Johnstone I. Interference competition and the functional response of oyster catchers searching for cockles by touch. Anim Behav. 1998;56:639-50.

14. Remsburg AJ, Olson AC, Samways MJ. Shade alone reduces adult dragonfly (Odonata: Libelluidae) abundance. J Insect Behav. 2008;21:460-8.

15. Varshini RA, Kanagappan M. Effect of quantity of water on the feeding efficiency of dragon fly nymph-Bradynopyga geminate (Rambur). J Entomol Zool Stud. 2014;2(6):249-52.

16. Halstead SB, Jacobson J. Japanese encephalitis vaccines. In: Plotkin SA, Orenstein WA, Offit PA, editors. vaccines. 5th ed. Philadelphia: Elsevier; 2008. p. 311-52.

17. Tiwari S, Singh RK, Tiwari R, Dhole TN. Japanese encephalitis: a review of the Indian perspective. Braz J Infect Dis. 2012;16(6):564-73.

18. Furtado JL, Mori S. The Ecology of a tropical freshwater swamp, the Tasek Bera, Malaysia. Hague: Dr. W. Junk Publishers; 1982.

19. Mohsin AKM, Ambak MA. Cyprinoid fishes of the Subfamily Cypriniod in Selangor. Malayan Nat J. 1982;35:29-55.

20. Tamaru CS, Cole B, Bailey R, Brown C. A manual for commercial production of the tiger barb, Capoeta tetrazona, a temporary paired tank spawner. Center for Tropical and Subtropical Aquaculture. 1997; 129.

21. Bertaco VA, Malabarba LRM. A new species of Hyphessobrycon (Teleostei: Characidae) from the upper rio Tocantins drainage, with bony hooks on fins. Neotropical Ichthyol. 2005;3(1):83-8. https://doi.org/10.1590/s1679 $-62252005000100004$

22. Lima FCT, Moreira CR. Three new species of Hyphessobrycon (Characiformes: Characidae) from the upper rio Araguaia basin in Brazil. Neotropical Ichthyol. 2003;1(1):21-33. https://doi.org/10.1590/S1679-6225200300 0100003.

23. Arjunan NK, Murugan K, Rejeeth C, Madhiyazhagan P, Barnard DR. Green synthesis of silver nanoparticles for the control of mosquito vectors of malaria, filariasis and dengue. Vector Borne Zoonotic Dis. 2012;12:262-8.

24. Zar JH. Biostatistical Analysis, fourth ed. Singapore: Pearson Education (Singapore) (Pte) Ltd., New Delhi (Indian Branch), India 1999.

25. Service MW. Mosquito ecology: field sampling methods. New York: Elsevier; 1983.

26. Chatterjee SN, Das S, Chandra G. Gold fish (Carrasius auratus) as a strong larval predator of mosquito. Trans Zool Soc India. 1997;1:112-4.

Ready to submit your research? Choose BMC and benefit from:

- fast, convenient online submission

- thorough peer review by experienced researchers in your field

- rapid publication on acceptance

- support for research data, including large and complex data types

- gold Open Access which fosters wider collaboration and increased citations

- maximum visibility for your research: over 100M website views per year

At BMC, research is always in progress.

Learn more biomedcentral.com/submissions 